\title{
Children's Perceptions of Folktales and Narration in Greece: Evidence from a Novel Micro-data Set
}

\author{
Athanasiadis Ilias (Corresponding author) \\ Assoc. Prof. \\ University of Aegean, Department of Primary Education \\ Rhodes, Greece \\ Tel: 30-2241-022947_E-mail: athanasilias@gmail.com \\ Papantonakis Georgios \\ Assoc. Prof. \\ University of Aegean, Department of Primary Education \\ Rhodes, Greece \\ Tel: 30-2241-022947Ｅ-mail: gepa@rho.forthnet.gr
}

Kaplanoglou Marianthi

Assist. Prof.

National and Kapodistrian University of Athens

Department of Byzantine Philology and Folklore Studies

Athens, Greece

Tel: 30-21-0727-7277Ｅ-mail: mkaplanog@phil.uoa.gr

Kaplanoglou Georgia

Assist. Prof.

National and Kapodistrian University of Athens

Department of Economic Sciences

Athens, Greece

Tel: 30-21-0368-9459 E-mail: gkaplanog@econ.uoa.gr

\begin{abstract}
This paper presents the results of a novel survey of pupils in Greek schools regarding children's opinions and ideas about folktales, as part of their culture, communication practices and as an educational tool. The survey was conducted during the school year 2004-2005 by scholars representing different scientific fields and universities. The sample consists of a large number of participants (2283 pupils from the last three classes of the Greek elementary school) and covers both urban and rural areas.

The purpose of this paper is to explore the complex relation of children with the world of folktales as a means of reshaping through them the known world. Therefore both the survey questionnaire and the subsequent results examine the role of folktales in children's cultural representations, family and intercultural relations and as part of the educational process. All these must be seen not only with the aim of utilizing folktales for educational purposes but also in designing the content, form, goals and methods of an alternative multicultural educational system.
\end{abstract}


In addition to demographic and family background information, the questionnaire addresses the two primary potential contexts of folktale diffusion in modern times, one private (the space of home and family) and one public (the school). It also examines the impact of the cultural industry in the formation of these perceptions.

Keywords: Folkloristics and education, Statistics, Children's folklore, Oral storytelling, Contextual method

\section{Theoretical definitions}

The relation of the folktale with their social, historical and cultural context has been introduced in folklore research from the beginning of the $20^{\text {th }}$ century and even earlier. Since the 1960 s and 1970 s it has received a further emphasis following an important shift of international scholarship to the socio-historical study and understanding of folk and fairy tales. In this respect, folktales were studied in the framework of oral storytelling in traditional societies (Dégh 1962, 1989), of the ethnography of performance (Bauman 1972, 1977), as an object of social history (Velay 1992) and as part of the educational, cultural and communication process (Zipes 1983, $1988,1990,1997,1999,2000)$. In the framework of these theoretical approaches, the relations among those who narrate, write or represent the folktale and those who receive it in its different forms were considered particularly important for the creation, reshapement, ideological meaning and function of the tales. The study of the interpenetration of folktales and society also focused on the relations among oral and written (printed) versions of folktales as well as on the new forms they take in the modern mass media, thus covering a vast field from oral tradition to culture industry and stressing the importance of folktales in the socialization process, at least in the Western societies.

A new theoretical perspective was opened up in the 1960s, where the study of interrelations between folklore and folklorism, introduced mainly by H. Moser and H. Bausinger, drew attention to the life of folklore in the contemporary consumption and media society (Moser 1962, 1964, Bausinger 1986, 2009). In contrast to the romantic study of traditional culture as a corpus of survivals and relics, which would disappear in contact with urban and technological civilisation, Hermann Bausinger introduced a systematic theory of expansion of folk culture, by giving emphasis to the historical dimension of the folk phenomena and studying modern folklore matters (urban folk culture, revival of folk culture, commercialization of tradition, new folk narrative genres etc). Under this new theoretical perspective folk culture was understood as a multidimensional and ever changing system where new and older elements were mixed. Furthermore, it was noticed that for many individuals and social groups folk culture represents, on the contrary, an "ideal" world of old values and symbols (thus defining their identity) juxtaposed to the expanded, modern and technological society.

In the light of these approaches the purpose of folkloric investigation is to describe the whole system of narrative potentials and realizations of a folktale in the framework of a society. According to the theory of folkloristics the narrative procedure depends not only on common esthetical rules, cultural values, social and historic experiences and a common stock of themes, forms and motifs but also on the narrators, their performances and the social institutions within which society gives them the opportunity to narrate. Therefore, the folktale, far from being a unified entity in the inherent plurality of oral tradition, was caught, in modern times, like other folk cultural goods, in the process of expansion; it was thus made available. This availability may have multiple meanings: loss of power, aestheticization, banishment, unleashing (Bausinger 2009, 92), its meanings, uses and functions multiplied.

Our understanding of the reception and use of the folktale in modern popular and mass culture is connected with these changes, in the framework of which folktales were connected with children, childhood and childlike worlds.

The connection and even the identification of folktales with children, that today seems natural, is only one stage in the historical evolution of the folktale. The tales of oral folk culture, even if they were part of family traditions, they were not generally destined for children only. Folktales were clearly directed to children from the moment they passed from oral to written and printed form, mainly during European romanticism, where the "invention" of tradition and the interest for the collection of folktales from the mouth of the "simple folk" led also to the appropriation of the folktales for children. This procedure, in many respects, continues until today.

Nevertheless the identification of folk and fairy tales with childhood in contemporary culture and market didn't facilitate their relationship with children (Meraklis 1999a, 203). Even if from different points of view (medical, educational, commercial etc.), children receive special care and attention, they are also facing many dangers, real (different forms of abuse or abandonment) or symbolic (the cultural products that are directed to the children have many analogies with products directed to adults, for example tv programs and serials). Thus many speak even about the disappearance of childhood (Postman 1982, Bausinger 1987, 20, Zipes 1997, 110-128). As a 
result, the relation of children with folktales becomes more difficult, since children abandon at an earlier stage the age of childhood in order to embrace the culture of grown-ups (Meraklis 1999a, 204).

Folk and fairy tales are caught in the middle of this contradiction which marks a more recent stage of their evolution: because of the infantile element they contain, they are used more and more as symbolic substitutes of this lost or wished childhood. Today they seem to address, as it was the case in traditional societies, people of all ages but this time as representations of childlike worlds. More than child lore, tales constitute today an imaginative land where grown-ups and children alike can find what life in contemporary societies has deprived them: the age of childhood in its entity. Under these conditions, folk and fairy tales or just the concept of "fairytale-like" element have penetrated many domains of contemporary culture.

Furthermore, children are ever more construed as available market audience in their own right as well as a key driver of consumption in home (Livingstone and Bovill 2001, 10). Folktales enter more and more the commercialized forms of this market which is increasingly penetrating the family home.

\section{Folk culture and folktales in the classroom}

Folklore and school have been considered as opposites: folklore representing an unofficial, multivariable, traditional culture whereas school symbolizing the bureaucratic structures of a state, reflecting its unified ideology. Nevertheless, the idea that folk expressions can be used as an educational tool gained ground during the educational reforms based on romantic nationalism. These educational reforms influenced what was known as progressive education or "the New Education" that occurred in both Europe and the United States in the late 19th century and early 20th century (Coe 2000, 25). For this education movement, preurban and preindustrial societies seemed to exemplify ideals of character and community that were disintegrating under the forces of city and factory (Coe 2000, Ross 1972; Strickland 1967). In fact only after the educational institutions have participated in dissolving the original horizons of traditional societies does the pedagogical principal of "Heimat" consciously lead back to the space once defined by these horizons (Bausinger 2009, 108-109). Thus contemporary children may experience former folk goods almost exclusively in the form of educational goods (Bausinger 2009, 109). Today in many countries, different initiatives for the insertion of folk culture in school curriculum have been taken either on a national or on a more restricted level. Nevertheless, in many cases, folk cultural expressions, through their representations in the official school curriculum, freeze in space and time, since they appear detached from their political and social contexts, either as a historical continuum or as exotic relics of a distant past.

This situation creates difficult problems for both the sciences of education and folkloristics. Folklorists have long contributed to a discussion between these two scientific fields while their applied practices were inspired by the principles of cultural pluralism and the methods of experiential education. The basic parameters of these studies refer to the role of folk culture in the learning process and in the aesthetic and psychological development of the child as well as its imaginative and narrative potentials; on issues related to inter-cultural teaching (like the creation of cultural bridges in the curriculum and the refutation of cultural deprivation theory); the role of folklore in education for connecting schools and communities (for example through the recognition of the value of uncommercialized artistic expressions); the research of continuities and discontinuities between the institutional (school) and not institutional (traditional) knowledge; and the problem of the disempowering assimilation of folklore brought into classrooms.

Folktales, more specifically, seem to have a central place in studies of folklorists and educationalists as they offer multiple reference points for didactic purposes (Note 1). This tendency is supported by a basic analogy between the world of the folktale and a child's imagination: the tradition attached to children is characterized by mythic thought and an inclination towards playing, as the child plays in a mythic way even when it mimics the real world (for example by drawing straight lines it makes a forest). The world of folktales matches this inclination of children to consider as naturally real what was just initiated by reality and then to freely develop it in an imaginative world (Meraklis 2001, 119).

The role of folktales in education has been studied in a systematic way by Kaspar Spinner (Spinner 1997) in the light of postmodernism, constructivism and cognitive psychology:

Folktales are both traditional and postmodern, since beside their deep historical roots and consistency, they are continuously retold, thus creating a playful relationship with their audiences. So it is possible to express, through these numerous retellings, the parody, the critique, the joy of narration, the personal anxieties, wishes and disappointments, the poetic and the magical. 
According to constructivism, the meaning of a text and therefore its aesthetic appreciation is not contained simply in the text but is defined by the personal experiences of each reader. This can be applied to the folktale which is open to multiple interpretations. Nevertheless folktales, as a narrative genre, were formulated, in a diachronic and collective manner, throughout history, which they reflect, so they cannot constitute simply the scenery where the experiences of an individual can be projected.

From the point of view of cognitive psychology, folktales are suitable for the learning process which regards pupils not as simple receivers of what we offer but as active and creative subjects. Children have the opportunity to understand and explain the tale according to their age.

This active and transitory aspect of children's engagement with folktales leads to a variety of questions instead of the usual one "how folktales influence children": about the role of folktales in children's imagination and creativity, the meaning that children themselves give to folktales, how the historical evolution of the folktale genre can influence the ways children perceive folktales today, the role of the folktale in parent-children communication and the use of folktales in the classroom.

\section{The content and methodology of the research}

In its different expressive forms, functions, mediums of diffusion and environments, folk and fairy tales in our society constitute an important part of the cultural goods addressed to children or created by them. In the framework of these multiple and even contradictory discourses about folktales, children, as the actual bearers of these traditions, were never asked for their opinion. The mapping of children's opinions and ideas about folktales, as texts but also as narrative procedures, do not merely refer just to another folk or literary genre but interfere more generally with children's cultural representations, individual and collective imagination and communication practices.

All these must be taken into account not only with the aim of utilizing them for educational purposes but also in designing the content, form, goals and methods of an alternative educational system. Therefore a study on the relation of children with folktales concerns the orientation of educational systems and methods and the perception of childhood in contemporary world.

The purpose of this research concerning the opinions of the pupils from elementary school about folktales is therefore to explore the complex relation of children with the world of folktales as a means of reshaping through them the known world. This can be done not only through qualitative research but also with the help of quantitative and statistical data. Thus this study aims at:

a) investigating the perceptions of schoolchildren about folktales and their basic dimensions (oral, text, image, locality and universality etc.),

b) examining the impact of the cultural industry in the formation of these perceptions,

c) examining the role of folktales in the formation of a communication and learning process through narration in family or school settings,

d) examining the role of folktales in the upbringing of children inside the family and in education.

The research was conducted during the school year 2004-2005 by Athanasiadis H. , Papantonakis G. and Kaplanoglou M. with the help of Malafantis K., Tsilimeni Tasoula, Moraiti T. and Stefos E., representing different scientific fields (Social Research, Children's Literature, Folkloristics and Pedagogy), and universities (University of the Aegean, University of Athens and University of Thessaly). The exact title of the survey was "The ideas of children about children's literature and the folktale" corresponding to two different but interrelated fields of research. Thus the research team decided, taking into consideration the volume of data produced after the analysis of the questionnaires and the tables, to proceed in two directions. The study about the ideas of pupils about children's literature took the form of a book already under print. Part of the results referring to the ideas of children about folktales will be presented here.

The research is characterized by a large sample of participants (2283 pupils from the $4^{\text {th }}, 5^{\text {th }}$ and $6^{\text {th }}$ class of the elementary school answered the questionnaires) as well as by an important diffusion of the research sample which contains both urban and rural areas: the prefectures of Attiki (Athens, East and West Attiki), Boiotia, the Dodekanese (the islands of Rhodes and Kalymnos) and Magnesie (with the island of Skiathos and Skopelos).

Unlike previous work that focuses to younger children in kindergarten or the first classes of the primary school, this research concerns children of the last three classes of primary school precisely because they are more likely to have a complex and complete view of folktales as listeners, readers and even narrators. 
In addition to demographic and family background information, the questionnaire addresses the two primary potential contexts of folktale diffusion in modern times, one private (the space of home and family) and one public (the school). Putting folktales in context will help us to understand the connection of children with folktales in the framework of family relations and within the school environment.

The survey also focused not merely to folktales as texts but to oral storytelling as a complex procedure, since storytelling can be found not only in traditional nonliterate societies but in modern ones too.

The questions of the survey were usually "closed", with the possibility of one or more answers (we used a five-point Likert-type scale of Very Frequently, Frequently, Occasionally, Seldom, and Never). Several questions were open with space for respondents to write words, phrases, or sentences.

The questionnaires were analyzed by the methods of descriptive statistics and of multivariate statistical analysis in order to study:

a) the response rate of the pupils

b) the distribution of their answers (in relation to gender and school class)

c) the differentiations in the sample and the possibilities of the creation of clusters, on the basis of the common answers in the entire questionnaire.

The answers were codified and were put in an Excel archive, where every column corresponded to one question and every line to one pupil that participated in the survey. The statistic outcomes and the statistic charts of the survey were produced with the help of the statistic software SPAD 4,5 (a copy of which belongs to the Department of Primary Education of the University of the Aegean). The cohesion tables were produced by the same statistic software.

It is obvious that the opinions and representations of children about folktales are to a great extent influenced by the general cultural ideas and the system where children live. Children's choices in relation to folktales, what they like or dislike are not necessarily the results of their own personal choices, but rather stem from complex family constrains, as well as cultural and consumption standards. But children are not passive consumers of these ideas but active people who enter a complex process of self-realization and socialization. Furthermore folktale, as a narrative genre with past and present, was used throughout its history to express even entirely contradictory ideas. These contradictions as well as the coexistence of simplified with more elaborated ideas can be found in children's thought.

\section{The analysis of results}

Socio-demographic characteristics of the sample

\section{Insert Figure 1 here}

The majority of pupils (about $85 \%$ ) declare Greece as their place of birth. Among the rest, slightly more than 5\% has been born in Albania, another $2.5 \%$ has been born in other countries, while about $7 \%$ of the pupils have not declared a country of birth. However, the place of birth of the children themselves should not necessarily be considered as a decisive factor influencing their cultural characteristics. The child's cultural background is influenced to a big extent by the place of birth of his/her parents, which may well differ among children with the same place of birth. For example, as documented in Table 1, while around half of the pupils in the sample have been born in Athens and its suburbs, only about $15 \%$ of their parents have been born in Athens themselves. In historical terms, this reflects the strong inner migration movement from rural to urban areas during the post war years until today. Similarly, while 169 pupils have been born in countries other than Greece, the same is true for 270 fathers and 293 mothers, reflecting the inflow of migrants mainly from countries of southeastern Europe after the 1980s. The diversion of the parent's origin among children born and/or studying in the same place is expected to make a difference regarding the child's view of folktales and is one of the factors to be further analyzed in the present paper.

\section{Insert Table 1 here}

\section{Insert Figure 2 here}

Each class represents about one third of the sample. The balanced distribution of sample members across gender and school class indicates that the sample is representative of the population and therefore one can expect that the expressed views on folktales are quite robust. Figure 2 defines also the geographical distribution of the pupils in relation to their place of residence: the survey was conducted in four parts of Greece were the researchers had access (Attica, Boiotia, the Dodekanese and Magnesie) which contain both urban as well as rural areas. 


\section{Insert Figure 3 here}

Insert Figure 4 here

The sample questionnaire also collects data on the educational level of the pupil's parents. This variable is considered important in shaping the cultural context of the pupil inside the family and therefore his/her interests and ideas. Around $60 \%$ of the parents have at most high-school education. Slightly over $25 \%$ of parents have tertiary or university education. On the whole, mothers tend to have a slightly lower education level compared to fathers.

The relation of pupils with folktales and storytelling

\section{Insert Table 2 here}

Table 2 presents the views of pupils on what a folktale is. It has to be stressed that this was an open-ended question and the answers were grouped in twelve categories. The fact that around $40 \%$ of pupils discern the imaginary/mythic element of folktales (categories 1 and 2) is quite remarkable. It demonstrates that many pupils recognize the main component that distinguishes folktales from other narrative genres, despite the fact that folktales are widely used in a variety of different contexts. On average $7.5 \%$ of pupils stress the funny/entertaining aspect of folktales, while another $5 \%$ (mostly girls) stress its educational/moral aspect. Only around $1 \%$ of the sample mention as the primary distinguishing aspect of folktales its oral and traditional character ("stories told by grandmothers"). Less than a quarter of boys and around $17 \%$ of girls did not answer.

\section{Insert Figure 5 here}

\section{Insert Figure 6 here}

\section{Insert Figure 7 here}

The vast majority of pupils (77\%) declare that they like folktales (see Figure 5). In fact, girls say that they like folktales in greater proportions than boys ( $83 \%$ and $71 \%$ respectively). This can be explained in terms of the fact that girls are more dedicated readers and listeners of books and stories. When asked whether they are told folktales, $50 \%$ of boys and $60 \%$ of girls answer positively. Furthermore, $64 \%$ of boys and $71 \%$ of girls read themselves folktales from books (Note 2).

If one tries to establish a relation between the age of the pupils and how fond they are of folktales, one will find out that younger pupils are fonder of folktales than elder ones. This result does not indicate that folktales are themselves suited better in mental terms to younger ages. It is rather a reflection of the social and cultural norms of modern times, according to which the folktale underwent a process of simplification and adaptation to younger ages.

\section{Insert Figure 8 here}

\section{Insert Figure 9 here}

Figures 8 and 9 are important in order to explore the importance of oral communication in the transmission of folktales today. In figure 8 we can see that pupils prefer to hear folktales in almost equal proportions with reading them. This has to be understood in terms of the fact that the Greek society is perceived as a society where oral communication plays an important role. As mentioned previously, half of the boys in the sample and more than half of the girls have listened to or are still listening to folktales.

We begin by exploring the oral transmission of folktales in the family context (see figure 9). If family is understood in a broader context (including grandparents), Figure 9 shows how often different family members narrate folktales to children. It becomes apparent that the female elder members of the family (mothers and especially grandmothers) tell folktales more often. Grandmothers appear to be the primary storytellers since $50 \%$ of pupils declare that they are very often or often told tales by their grandmother. $40 \%$ of pupils declare that they are very often or often told tales by their mothers. Grandfathers follow with $28 \%$, while fathers appear to be the ones least occupied with storytelling (26\%). This might itself be a reflection of the fact that female members of the family spend more of their time taking care of children. Further analysis of the results (not presented here due to space constraints) confirms the fact that girls are more eager listeners compared to boys. On the whole, oral storytelling seems to comprise a vivid activity within the Greek family.

\section{Insert Figure 10 here}

Folktales can be told to children either by reading them from a book or by narrating them by heart. As regards this distinction, Figure 10 shows that parents prefer to read tales from books, while grandparents prefer to narrate by heart. This partly suggests that grandparents have a richer knowledge of the oral traditional culture. 


\section{Insert Figure 11 here}

Turning to the oral transmission of folktales in the school context, results come to direct contrast to what we have already established for the family level. As shown in Figure 11, it becomes apparent that folktales are not used as means of oral communication or as an educational tool. Over $60 \%$ of pupils report that their teachers rarely or never tell them folktales by heart. Since some folktales are included in school books, about $34 \%$ of pupils report that their teacher reads to them tales out of school books. Narration from trade books (i.e. children's literature) is also uncommon. This evidence could suggest that the teaching methods are still primarily based on written and printed texts, instead of reinforcing the learning process inside the classroom, through other mediums, such as oral communication (Note 3 ).

This situation can be better understood from a historical perspective which would study the notions around folk culture that have become established in modern Greece. The processes by which cultural formations were integrated in Greek society are reflected in the way in which contemporary educational mechanisms conceive culture. The way the school deals with folk culture is to a great extent determined by the dominant ideologies and almost never on the basis of scientific theories. Although certain aspects of Greek folk culture are included in the teaching material of other subjects, folk culture itself is not taught and furthermore, there is no effort made for a systematic contact of the pupils with folk tradition. Despite the fact that folklore studies are indeed part of the course programme of some university departments of primary education, on the whole the teachers' background in folklore is certainly not sufficient to allow them to teach it themselves. Any related educational activities are only done as part of experimental or small scale programmes (such as the important initiative "Programme for the Teaching of Greek Folk Culture in Primary and Secondary Education" (1997-1998) directed by M. Meraklis and R. Kakamboura - Tili or the Program "Melina-Education and Folk Culture" (1994-2004) or result from initiatives taken by interested teachers, students and parents (for example, original publications of folktales collected by pupils from their grandparents).

Dominant ideologies (including school policies) seem to promote folk culture almost exclusively as a static, idealized entity that is connected to the glorious national past or as a concept of locality against the power of market globalisation. Within this context, educational activities are extended outside the classroom, focusing on the folk community that produces and constantly supplies culture. For example, pupils are encouraged to take part in school parades dressed in local costumes.

\section{Insert Figure 12 here}

In cases folktales are told in the classroom, they seem to encourage a range of creative activities (see Figure 12 above). Painting and theatrical play are the most common such activities, while many pupils involve themselves in writing their own tales and/or collecting them from their relatives. Such activities are in most cases complementary and cultivate both the aesthetic and expressive abilities of children.

\section{Insert Figure 13 here}

Storytelling is not a one-way process directed towards children. Children themselves seem to enjoy telling tales primarily to other children, but also to adults (mainly of their own family).

\section{Insert Figure 14 here}

Turning to the ways kids have access to fairytales other than oral communication, Figure 14 shows that children learn folk and fairytales from a variety of sources. Conventional sources (like books) come first, while technologically advanced sources (like DVD, cinema and television) seem to have gained ground. Children theatre (were we may include puppet theatre and shadow theatre, both of which are very common in Greek culture) is also considered a popular source of tales. Computers seem to be more popular among boys. Finally, a small percentage of pupils mention telephone as a means of accessing folktales, which partly reflects the fact that government institutions have recently established tale telephone services.

\section{Insert Figure 15 here}

Figure 15 shows the answers to the open-ended question on which folktales kids knew apart from the five most popular ones (Red riding hood, Snowhite, Cinderella, Puss in Boots and The three little pigs). The latter stories were excluded because they are the ones anyway most frequently mentioned by kids. Pupils' answers were grouped in nine categories on the basis of the folktales characteristics. Two main conclusions can be drawn.

The first one is that traditional folk tales (including tales of Greek oral tradition as well as literary versions of European folktales written mainly by the great writers of the $19^{\text {th }}$ century like the brothers Grimm and Hans Christian Andersen) are the ones most frequently mentioned, suggesting that these stories still have a great 
impact on the imagination of contemporary children. Within this category we identified two subgroups, folk tales and folk tales with animals. Slightly under half of pupils mentioned a folk tale and around $38 \%$ mentioned a folk tale with animals. The popularity of folk tales in modern times reflects the fact that such tales directly fit to the perceptive abilities and address the psychological needs of modern children. This can be explained by the power of folk tales to absorb the wisdom of different peoples through time and space and therefore appear appealing to children today regardless of cultural and social background. The role of the structure of the Greek family and its cultural preferences should also not be undermined.

The second conclusion one may draw from Figure 15 is that the variety of the pupils' answers is not created by an initial confusion about folktales as a genre but rather is based on the fact that apparently many new forms of cultural products directed to children are based on or include elements of folk tales (Note 4). The literature on the sociology of childhood provides evidence that the most popular cultural products addressed to children are the ones derived from children's games, older and recent ones. Gillles Brougère supports that kids by reproducing tales from television and the cinema, rediscover in these tales elements from their own culture to which they have access from other mediums as well (Brougère 2006).

Additionally popular tv or cartoon series and videogames addressed to children (for example, Pokemon or Gormitti) include folk tale elements. The vast diffusion of folk tale elements in different cultural products (in accordance to the procedure of the expansion of fairytales discussed above) partly explains the confusion that exists today on the term fairytale.

\section{Insert Figure 16 here}

Pupils were also asked whether they believe that Greek folktales resemble those of other countries. More than half answered that they do not know, while the rest answered positively or negatively in equal proportions. These answers could partly reflect the failure of formal educational policies to exploit the multicultural character of Greek schools today. Furthermore, the unpretentious declaration of ignorance by the majority of pupils shows that kids have no stereotypes on this issue and would therefore be open to a potentially informed scientific view of teachers.

Further elaboration of primary data would reveal another interesting yet not surprising aspect of this issue. It seems that kids who have at least one parent born outside Greece in much larger proportions believe that Greek folktales do resemble those of other countries. This may reflect the fact that these kids wish to feel closer to the culture of the country were they live and/or that they indeed by having access to different cultures (that of their family of origin and that of the place they live) can appreciate the similarities between these cultures. Such views constitute yet another element to be exploited in a process of designing an alternative approach to education that would aim at alleviating tensions within the school environment and lead to a fairer treatment of all pupils.

\section{Conclusions}

This paper examined the diffusion and significance of folktales among children by considering new tales in the context of older ones, tales' use in the context of storytelling and storytelling in the context of the rest of children's lives.

According the results of this survey, folk and fairy tales, instead of being replaced by other imageries that succeeded them, like science fiction stories or modern legends, seem to coexist with them.

For Greek schoolchildren these older stories stem either from the Greek folk tradition diffused through oral or written (printed) channels or from adaptations of the literary fairy tales of the West European tradition of the $19^{\text {th }}$ and the beginning of the $20^{\text {th }}$ centuries.

The endurance of these traditional stories in children's imagination and culture may be attributed to a number of reasons: As far as Greek folk tradition is concerned, we are facing a narrative material which didn't remain fixed in time but continued to change in order to meet the needs of the social groups that created the stories, absorbing transnational as well as local elements (for example a folktale which is popular in one part of Greece may be less known in another). This is evident from the analysis of the numerous oral versions collected in various parts of Greece until today. This material, which is characterized by its multiplicity, is possible to reach children via oral storytelling or from printed collections of folktales adapted for children.

On the contrary, the connection of modern children with the classic fairy tales of the West European tradition is based on the knowledge of a rather fixed and limited number of tales in comparison with those actually written by the classic storytellers of the $19^{\text {th }}$ and the beginning of the $20^{\text {th }}$ centuries. This corpus of tales was furthermore popularized through adaptations in literature, cinema and the industry of consumption, so that these tales are actually less known in the form of stories and more in the form of images or brand (logo) names. 
The fact that new stories may use, either in a creative or in a fragmentary or trivial manner, the symbolic framework of older ones, resulting to the reutilization of the latter and so, in certain cases, to their reestablishment, is a matter that also requires further investigation.

From the different contexts of use of folk and fairy tales, this survey focused on oral storytelling not because it represents a traditional way of folktale diffusion but because it permits to explore the dimensions and potentiality of orality and the goods of an oral culture in a world of texts and images.

The findings of the survey show that the space of home and family as well as children themselves as an age category provide a favorable framework for oral storytelling. This is not the case for the school environment where neither folktales nor storytelling seem to have found their place. The educational value of folktales having long been established, this may be attributed to the general orientation of the educational system, and more specifically to the underestimation of folk culture in the school curriculum and activities where it is only fragmentarily used in the narrow borders imposed by dominant ideologies.

19th century disputes about the use of fairytales in education reflect the uneasiness of adults over the nature of childhood and their tendency to tame children's imagination. Moreover, suspicion about folktales arouse from their folk cultural origin, so they reached school through their literary adaptations which contained the appropriate moralistic and pedagogical messages. These oppositions frame modern debates too on the same matter while a new source of anxiety for parents and educationalists stem from the new technological or media forms of imagery and their influence upon children's imagination.

As demonstrated by the results presented in this paper, within these rapidly changing social and cultural frameworks, folktales and storytelling are part of folk culture and also part of children's folklore repertoires. From a policy perspective, as such, their potential role in stimulating creative initiatives inside the school curriculum is invaluable. As stated by Richard Bauman in his ethnography of children's folklore, "The indigenous art forms of childhood might constitute a significant resource in the development of culturally responsive, locally relevant art forms in the schools" (Bauman 1982).

Furthermore, the use of the folktales and storytelling as a teaching material in diverse school activities or more generally a more systematic contact of the pupils with folk culture presupposes the training of teachers on folklore on the basis of the scientific theories of folkloristics.

\section{References}

Abrahams, R., \& Troike, R. (Eds.). (2000). Language and Cultural Diversity in American Education. Englewood Cliffs, N.J.: Prentice-Hall 1972.

Anagnostopoulos, V.D. (Eds.). (1999). Folk tradition and school (in greek). Kastaniotis Editions, Athens.

Antoniadis-Bibicou, H. (1996). Recherches sur les conditions historiques de la formation du différent et du commun dans la culture des pays balkaniques. Études Balkaniques - Cahiers Pierre Belon, vol. 3, 5-27.

Avdikos, E. (1999). Once upon a time but it can be now. Education as the space of formation of storytellers (in greek). Ellinika Grammata, Athens.

Banks, J. (1994). An Introduction to Multicultural Education. Boston: Allyn and Bacon.

Barton, B. (1986). Tell me another: storytelling and reading aloud at home, at school and in the community. Canada, Heinemann.

Barton, B. (1988). Bringing the story to life in Story and storytelling. Language Matters, Numbers 2 \& 3, London, Centre for language in primary education, 5-9.

Bauman, R. (1972). Differential Identity and the Social Base of Folklore, in Americo Paredes and Richard Bauman (Eds.), Toward New Perspectives in Folklore (pp.31-41). University of Texas Press for the American Folklore Society Austin.

Bauman, R. (1977). Verbal Art as Performance. Prospect Heights, Ill.: Waveland Press.

Bauman, R. (1982). Ethnography of Children's Folklore, in Perry Gilmore and Allan Glatthom (Eds.), Children in and Out of School: Ethnography and Education (pp.172-186). Center for Applied Linguistic, Washington, D.C.

Baumer, S., Ferholt, B., \& Lecusay, R. (2005). Promoting narrative competence through adult-child joint pretense: Lessons from the Scandinavian educational practice of playworld, Cognitive Development, 20, 576-590. 
Bausinger, H. (1986). Towards a critique of folklorism criticism. in J. Dow, \& H. Lixfeld (Eds.), German Volkskunde (pp.113-23). Indiana University Press, Bloomington.

Bausinger, H. (1987). Märchen, Phantasie und Wirklichkeit (Jugend und Medien, Bd 13). dipa - Verlag, Frankfurt am Main.

Bausinger, H. (2009). Folk culture in a world of technology (in greek, translated by M. Kaplanoglou, \& A. Kontogiorgi). Patakis editions.

Ben-Amos, D. (1971). Toward a Definition of Folklore in Context. Journal of American Folklore, 84/331, 3-15.

Ben-Amos, D. (1992). Folktale. in Richard Bauman (Eds.), Folklore, Cultural Perfomances and Popular Entertainements (pp.101-118). Oxford University Press, New York.

Blatt, G.T. (Eds.). (1993). Once Upon a Folktale: Capturing the Folklore Process with Children. Teachers College Pr/Columbia U Pr, New York.

Bowman, P., \& Bartis P. (1994). A Teacher's Guide to Folklife Resources for K-12 Classrooms. American Folklife Center, Washington, D.C.

Brougère, G. (2006). Barbie, GI Joe, Pokémon et les autres; Les jouets et les mutations de la culture enfantine contemporaine. Compte-rendu par Emmanuel Pasquier, MSH Paris Nord.

Cazden, C., \& Hymes, D. (1978). Narrative and Story-Telling Rights: A Folklorist's Clue to a Critique of Education. Keystone Folklore, 22, 21-36.

Chevalier, M. (1995). Maintaining an Ethnic Identity in School: A Folkloric Perspective. Equity and Excellence in Education, 28, 26-35.

Coe, C. (2000). The education of the Folk Peasant Schools and Folklore Scholarship, Journal of American Folklore, 113/447, 20-43.

Collins, F. (1999). The Use of Traditional Storytelling in Education to the Learning of Literacy Skills. Early Child Development and Care, 152/1, 77 - 108.

Cortazzi, M., \& Lixian, J. (2007). Narrative learning, EAL and metacognitive development. Early Child Development and Care, 177/6 \& 7, 645-660.

Danielson, L. (1976). The Uses of Folk Literature in the English Classroom. Illinois English Bulletin, 64/1, 13-21.

Dégh, L. (1962). Märchen, Erzähler und Erzählgemeinschaft, dargestellt an der ungarischen Volksüberlieferung. Deutsche Akademie der Wissenschaften zu Berlin.

Dégh, L. (1989). Folktales and society: story-telling in a Hungarian Peasant Community. ( $1^{\text {st }}$ ed. 1962, translated by Emily M. Schossberger). Indiana University Press, Bloomington and Indianapolis.

Dolle-Weinkauff, B. (1999). Nineteenth-Century Fairy Tale Debates and the Development of Children's Literature Criticism in Germany. Children's Literature Association Quarterly, 24/ 4, 166-173.

Dorson, R., \& Carpenter, I. (1978). Can Folklorists and Educators Work Together? North Carolina Folklore Journal, 26, 3-13.

Dorst, J. (1990). Tags and Burners, Cycles and Networks: Folklore in the Telectronic Age. Journal of Folklore Research, 27, 179-190.

Fox, C. (1992). You sing so merry those tunes. Oral storytelling as a window on young children's language learning. in K. Kimberly, M. Meek, \& J. Miller, (Eds.), New readings: contributions to an understanding of literacy. A. and C. Blac, London.

Fox, C. (1993). At the very edge of the forest: the influence of literature on storytelling by children. Cassell, London.

Fox, C. (1998a). Poppies will make them grant. in M. Meek, \& C. Mills, (Eds.), Language and literacy in the primary school. Falmer Press, Lewes.

Fox, C. (1998b). Children thinking through story. English in education, 23/2, 27-38.

Greenfield, P., Farrer, D., \& Beagles-Roos, J. (1986). Is the medium the message? An experimental comparison of the effects of radio and television on imagination. Journal of Applied Developmental Psychology, 7/4, 237-255. 
Greenfield, P., \& Beagles-Roos, J. (1988). Radio versus television: Their cognitive impact on children of different socio-economic and ethnic groups. Journal of Communication, 38/2, 71-2.

Grider, S. (1995). Passed Down from Generation to Generation: Folklore and Teaching. Journal of American Folklore, 108, 178-185.

Hamer, L. (2000). Folklore in Schools and Multicultural Education. Toward Instutionalizing Nonistitutional Knowledge. Journal of American Folklore, 113/447, 44-69.

Hatzitaki-Kapsomenou, H. (2002). To neoelliniko laiko paramythi (The neohellenic Greek Folktale). The Institute of Modern Greek Studies - Manolis Triantafyllidis Foundation, Thessaloniki.

Haut, J.E. (1991). Folklore in the Classroom: $19^{\text {th }}$-Century Roots, $20^{\text {th }}-$ Century Perspectives. Western Folklore, $50,65-73$.

Howe, A., \& Johnson, J. (Eds.). (1992). Common bonds: storytelling in the classroom. Hodder and Stoughton, London.

Kakamboura-Tili, R. (2000). Program of teaching folk culture in primary and secondary education. (in greek). Synchrono Nipiagogio, 14, 16 - 24.

Kaplanoglou, M. (2002). Paramythi kai afigisi stin Ellada: mia palia texni se mia nea epoxi (Folktale and storytelling in Greece: an old art in a new era). Patakis editions, Athens.

Lange, G. (Hrsg.). (2010). Märchen. Märchenforschung. Märchendidaktik. Schnedier Verlag Hohengehren $\mathrm{GMbH}$, Baltmannsweiler.

Lemish, D. (2009). Children and Television, A Global Perspective (in greek), transl. by E. Kourti. Ekdosis Topos, Athens.

Livingstone S. and M. Bovill, Children and their changing media environment: A European comparative study. Lawrence Erlbaum, Mahwah NJ 2001.

MacDonald, M.R. (1999). Functions of Storytelling. in M.R. MacDonald (Eds.), Traditional Storytelling Today. An International Sourcebook (pp.408-415). Fitzroy Dearborn Publishers, Chicago - London.

Meraklis, G.M. (1999). Folktale. Texts about the study of folktales (in greek). Ellinika Grammata editions, Athens.

Meraklis, G.M. (2001). Pedagogical issues about folklore (in greek). Iolkos, Athens.

Moser, H. (1962). Vom Folklorismus in unserer Zeit. Zeitschrift für Volkskunde, 58, 177-209.

Moser, H. (1964). Der Folklorismus als Forschungsproblem der Volkskunde. Hessische Blätter für Volkskunde, 55, 9-57.

Opie, I., \& Opie, P. (1959). The Lore and Language of Schoolchildren. Clarendon Press, Oxford.

Papantonakis, G., Athanasiadis, I., \& others. (2010). Oi idees ton paidion gia tin paidiki logotexnia (The ideas of children about children's literature). Topos editions. Athens.

Pöge-Alder, K. (2007). Märchenforschung. Theorien - Methoden - Interpretationen. Narr, Tübingen.

Postman, N. (1982). The Disappearance of Childhood. Vintage Books, New York.

Rolandelli, D.R. (1989). Children and television: The visual superiority effect reconsidered. Journal of Broadcasting and Electrionic Media, 33/1, 69-81.

Rosen, B. (1988). And none of it was nonsense: the power of storytelling in school. Mary Glasgow Publications, London.

Rosen, B. (1991). Shapers and polishers: teachers as storytellers. Mary Glasgow Publications, London.

Ross, D. (1972). G. Stanley Hall: The Psychologist as Prophet. University of Chicago Press, Chicago.

Schacker, J. (2003). National Dreams. The Remaking of Fairy Tales in Nineteenth-Century England. University of Pennsylvania, Press Philadelphia.

Shuttleworth, S. (2003). The Psychology of Childhood in Victorian Literature and Medicine. in H. Small \& T. Tate, (Eds.). (2003). Literature, Science and Psychoanalysis 1830-1870-Essays in Honour of Gillian Beer (pp.86-101). Oxford UP, Oxford.

Skourtou, E. (1995). Some notes about the relationship between bilingualism and literacy concerning the teaching of Greek as a second language. European Journal of Intercultural Studies, 6/2, 24-30. 
Skourtou, E., \& Kourtis-Kazoullis, V. (2000). Language Diversity and Second and Foreign Language Learning. in G. Thill (Eds.), Sustainable Development in the Islands and the Roles of Research and Higher Education, Proceedings, Vol 2, Prelude, Brussels.

Skourtou, E. (2002). Connecting Greek and Canadian schools through an Internet-based sisterclass network. International Journal of Bilingual Education and Bilingualism, 5/2, 85-94.

Spinner, H.K. (1997). Märchendidaktik heute. in K. Wardetzky/H. Zitzlsperger (Hrsg.), Märchen in Erziehung und Unterricht heute (pp.48-65). Bd. I. Rheine: Europäische Märchengesellschaft.

Spinner, H.K. (2003). Märchenalter. Bemerkungen zu einem umstrittenen Begriff“, in T. Jesch (Hrsg.): Märchen in der Geschichte und Gegenwart des Deutschunterrichts. Frankfurt a. M.: Lang 2003, 41-51.

Steedman, C. (1995). Strange Dislocations: Childhood and the Idea of Human Interiority, 1780-1930. Virago, London.

Strickland, C.E. (1967). The Child, the Community, and Clio: The Uses of Cultural History in Elementary School Experiments of the Eighteen-Nineties. History of Education Quarterly, 7/4, 474-492.

Sullivan, C.W. (1990). Narrative Expectations: The Folklore Connection. Children's Literature Association Quarterly, 15/2, 52-55.

Sumpter, C. (2006). Innocents and Epicures: The Child, the Fairy Tale and Avant-garde Debate, fin-de-siècle Little Magazines, Nineteenth-Century Contexts, 28/3, 225-244.

Sutton-Smith, B., Mechling, J., et.al., (Eds.). (1995). Children's Folklore: A Source Book. Garland Publishing, Inc., N.Y.

Bourne, T.J. (1998). Between Atavism and Altruism: The Child on the Threshold in Victorian Psychology and Edwardian Children's Fiction. Children in Culture (pp.88-121). Ed Karín Lenik-Oberstein. Basingstoke: Macmillan.

Untiedt, K.L. (Eds.). (2005). Inside the Classroom (and Out): How we learn through Folklore. Publications of the Texas Folklore Society, Denton, Texas, University of North Texas Press.

Velay-Vallantin, C. (1992). L' histoire des contes. Fayard, Paris.

Wardetzky, K. (1992). Märchen-Lesarten von Kindern: Eine empirische Studie. Peter Lang, Berlin.

Wardetzky, K., \& Zitzlsperger, H. (2005). Märchen in Erziehung und Unterricht heute. Königsfurt Urania, Kiel.

Wolf-Knuts, U., \& Kaivola-Bregenhøj, A., (Eds.). (2001). Pathways: Approaches to the Study and Teaching of Folklore. Nordic Network of Folklore.

Zipes, J. (1983). Fairy tales and the art of subversion. Wildman London.

Zipes, J. (1988). The Brothers Grimm: from enchanted forests to the modern world. Routledge, Chapman and Hall, New York.

Zipes, J. (1990). The Origins of the Fairy Tale for Children or, How Script was Used to Tame the Beast in Us. in Avery G., \& Briggs J., (Eds.), Children and their Books: a Celebration of the Works of Iona and Peter Opie. Claderon Press, Oxford.

Zipes, J. (1995). Creative storytelling, building community, changing lives. Routledge, London - New York.

Zipes, J. (1997). Happily ever after. Fairy tales, children, and the culture industry. Routledge, New York and London.

Zipes, J. (1999). When dreams came true. Classical fairy tales and their tradition. Routledge, New York and London.

Zipes, J. (2000). The Oxford Companion to Fairy Tales. The western fairy tale tradition from medieval to modern. Oxford University Press, Oxford.

\section{Notes}

Note 1 . The use of folk and fairy tales for educational purposes, introduced from the second half of the $19^{\text {th }}$ century, initiated many disputes among pedagogues, teachers and educationalists, like those expressed in Germany by the movement of Herbart $\kappa a l$ Ziller and later by the initiative of Linder $\kappa a l$ Köster (Dolle-Weinkauff 1999), since of all children's literature, folktales were regarded to be the most subversive and also the most closely connected to child psychology (Shuttleworth 2003, Steedman 1995, Sumpter 2006, Taylor 1998). Gradually folktales were used in education either as an end in itself (for example they constituted the 
central object of educational reforms dealing with the role of creativity and imagination in the learning process or, more recently, they were put in the service of multicultural education or of the concept of edutainement) or as educational tools, in the service of diverse educational purposes (for example for the acquisition of language skills by the smaller children, for the understanding of mathematical concepts etc). In a substantial body of research, scholars have documented the multiple benefits of using folktales with children and (or) in classrooms to support teaching methods.

Note 2. As mentioned by Georgios Papantonakis, H. Athanasiadis and others in the relevant research about children's literature, in the question "which children's books interest you more", books of fairytales and myths or stories of fantasy are among the reading pupils strongly prefer, with girls saying that they like this kind of children's literature in greater proportions than boys $(52,98 \%$ and $42,97 \%$ respectively for the books of fairytales and myths and $55,39 \%$ and $49,52 \%$ for texts of fantasy). Additionally in question "I must read children's literature in order to...", the answer "to develop my imagination" is given by the $80,59 \%$ of the girls and $71,35 \%$ of the boys. This choice of the pupils also shows that they read children's literature for aesthetic and not for didactic reasons.

Note 3. The importance and function of storytelling and listening to stories, especially in primary education, for the development of narrative skills, language learning, the access to literacy, strengthening of children's creativity, co-operation, and social awareness, initiation to one's own culture, and intercultural understanding has been pointed out in numerous educational studies (Barton, 1986, 1988, Baumer 2005, Ferholt and Lecusay 2005, Collins 1999, Cortazzi and Jin 2007, Fox 1988, 1989, 1992, 1993, Howe, A. and Johnson, J. 1992, Rosen 1988, 1991, Sullivan 1990, Zipes1995). As stated by Eleni Skourtou, the linear passing from oral to written language is replaced today by multimodal ways to learning, so that oral, written word, images, sounds coexist in diverse configurations. Since many schools in Greece, as elsewhere, are culturally and linguistically diverse, the role of oral communication in relation with the acquisition of literacy skills by bilingual pupils is particularly important (Skourtou 1995, 2002, Skourtou and Kourtis-Kazoullis 2002). Furthermore, multiple researches on the subject of the cognitive impact between verbal-listening mediums of understanding (like radio) and visual mediums (like television), conclude that hearing a story on radio may stimulate the ability of creating a new story in a greater extent than seeing it on television (Greenfield, Farrer and Beagles - Roos 1986, Greenfield and Beagles - Roos 1988, Rolandeli 1989). Thus one may assume that the oral or written form of a story stimulates creativity more than its version on television (Lemish 2009, 68).

Note 4. See also the comparison made by Hermann Bausinger among the folktale, the "phantastische Jugendliteratur" and science fiction stories in Hermann Bausinger, Märchen, Phantasie und Wirklichkeit (Jugend und Medien, Bd 13), dipa - Verlag, Frankfurt am Main 1987.

Table 1. Place of birth of the pupils and their parents

\begin{tabular}{|l|l|l|l|l|l|l|}
\hline \multirow{2}{*}{ Place of birth } & \multicolumn{3}{|l|}{ Pupils } & \multicolumn{2}{l|}{ Father } & \multicolumn{2}{l|}{ Mother } \\
\cline { 2 - 7 } & \multicolumn{1}{|c|}{$\mathrm{n}$} & \multicolumn{1}{c|}{$\%$} & $\mathrm{n}$ & $\%$ & $\mathrm{n}$ & $\%$ \\
\hline $\begin{array}{l}\text { Athens-Piraeus } \\
\text { and suburbs }\end{array}$ & 1142 & 50,02 & 328 & 14,37 & 348 & 15,24 \\
\hline Thessaloniki & 26 & 1,14 & 37 & 1,62 & 52 & 2,28 \\
\hline $\begin{array}{l}\text { Central Greece } \\
\text { and the rest of } \\
\text { Attica }\end{array}$ & 124 & 5,43 & 208 & 9,11 & 206 & 9,24 \\
\hline Peloponnese & 39 & 1,71 & 175 & 7,67 & 140 & 6,13 \\
\hline Aegean islands & 258 & 11,30 & 199 & 8,72 & 221 & 9,68 \\
\hline Crete & 9 & 0,39 & 66 & 2,89 & 57 & 2,50 \\
\hline Ionian islands & 6 & 0,26 & 39 & 1,71 & 33 & 1,45 \\
\hline Thessaly & 306 & 13,40 & 212 & 9,29 & 202 & 8,85 \\
\hline
\end{tabular}




\begin{tabular}{|l|l|l|l|l|l|l|}
\hline Epirus & 18 & 0,79 & 74 & 3,24 & 80 & 3,50 \\
\hline Macedonia & 11 & 0,48 & 57 & 2,50 & 42 & 1,84 \\
\hline Thrace & 8 & 0,35 & 21 & 0,92 & 25 & 1,10 \\
\hline Cyprus & 0 & 0,00 & 5 & 0,22 & 3 & 0,13 \\
\hline Albania & 117 & 5,12 & 157 & 6,88 & 165 & 7,23 \\
\hline $\begin{array}{l}\text { Other Balkan } \\
\text { country }\end{array}$ & 15 & 0,66 & 22 & 0,96 & 21 & 0,92 \\
\hline $\begin{array}{l}\text { Country of the } \\
\text { ex-Soviet Union }\end{array}$ & 9 & 0,39 & 11 & 0,48 & 16 & 0,70 \\
\hline West Europe & 16 & 0,70 & 26 & 1,14 & 33 & 1,45 \\
\hline East Europe & 1 & 0,04 & 5 & 0,22 & 5 & 0,22 \\
\hline Scandinavia & 0 & 0,00 & 7 & 0,31 & 4 & 0,18 \\
\hline Near East & 4 & 0,18 & 6 & 0,26 & 12 & 0,53 \\
\hline America & 4 & 0,18 & 9 & 0,39 & 8 & 0,35 \\
\hline Asia & 0 & 0,00 & 5 & 0,22 & 7 & 0,31 \\
\hline Africa & 0 & 0,00 & 8 & 0,35 & 8 & 0,35 \\
\hline Australia & 3 & 0,13 & 9 & 0,39 & 11 & 0,48 \\
\hline No answer & 167 & 7,33 & 599 & 26,24 & 584 & 25,58 \\
\hline Total & 2283 & 100,00 & 2283 & 100,00 & 2283 & 100,00 \\
\hline
\end{tabular}

Table 2. Percentages of pupils in relation with their answers about the definition of the term folktale

\begin{tabular}{|l|l|l|l|l|}
\hline \multirow{2}{*}{} & \multicolumn{2}{|c|}{ Boys } & \multicolumn{2}{c|}{ Girls } \\
\cline { 2 - 5 } & \multicolumn{1}{|c|}{$\mathrm{n}$} & \multicolumn{1}{|c|}{$\mathrm{n}^{\mathrm{N}}$} & \multicolumn{1}{c|}{$\%$} \\
\hline A mythic story - a story with mythic heroes & 131 & 11,44 & 101 & 8,99 \\
\hline An imaginative story / book & 354 & 30,92 & 396 & 35,26 \\
\hline $\begin{array}{l}\text { An entertaining / pleasant story / a story that makes you } \\
\text { laugh }\end{array}$ & 71 & 6,20 & 95 & 8,46 \\
\hline Different kinds of stories & 100 & 8,73 & 108 & 9,62 \\
\hline $\begin{array}{l}\text { A story that teaches you a lesson/ an educational/moralized } \\
\text { story }\end{array}$ & 27 & 2,36 & 33 & 2,94 \\
\hline Stories told by grandmothers & 12 & 1,05 & 10 & 0,89 \\
\hline A story that teaches you something good & 32 & 2,79 & 38 & 3,38 \\
\hline A true story & 12 & 1,05 & 12 & 1,07 \\
\hline A children's story & 46 & 4,02 & 46 & 4,10 \\
\hline Nonsense & 5 & 0,44 & 13 & 1,16 \\
\hline Different generalized answers & 81 & 7,07 & 76 & 6,77 \\
\hline Don't know/don't answer & 274 & 23,93 & 195 & 17,37 \\
\hline Total & 1145 & 100,00 & 1123 & 100,00 \\
\hline
\end{tabular}




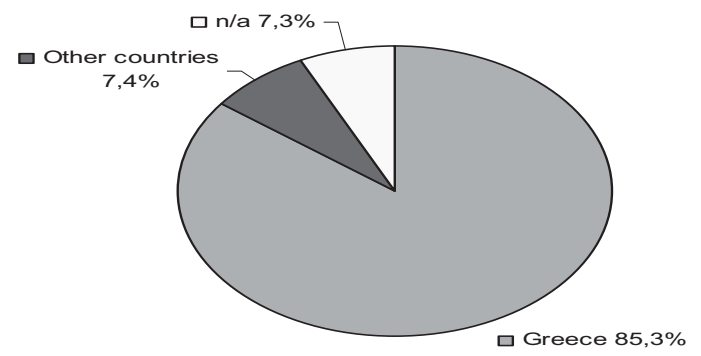

Figure 1. Percentages of the pupils in relation with their place of birth

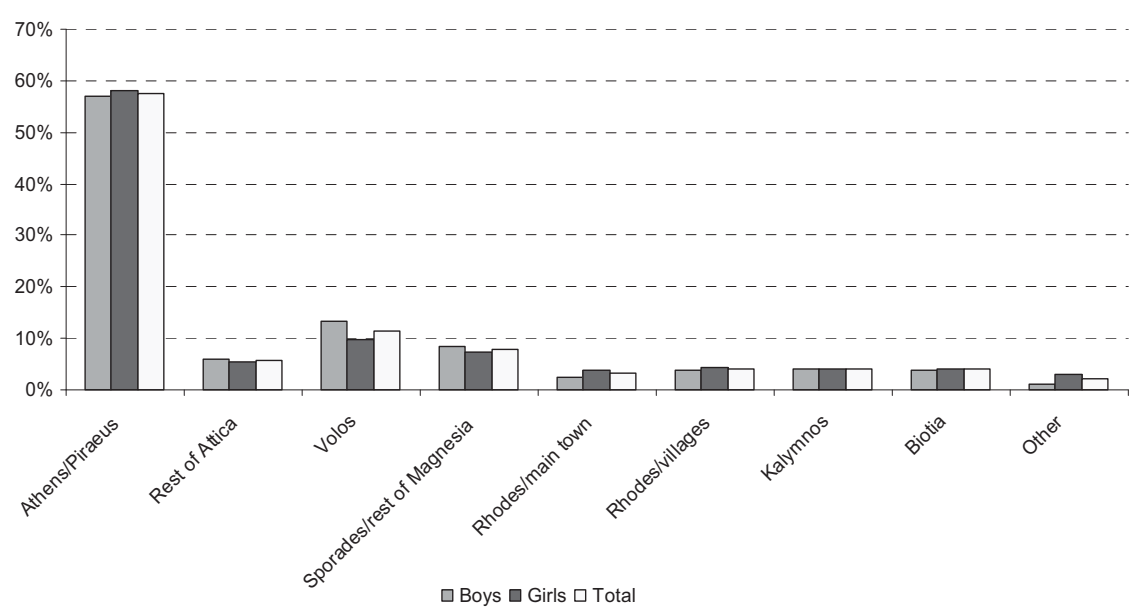

Figure 2. Distribution of boys, girls and the totality of pupils in relation to place

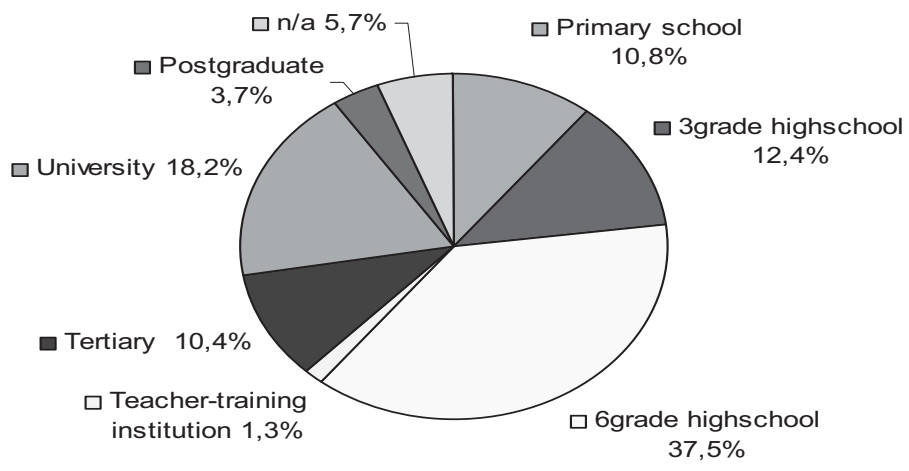

Figure 3. Percentages of the pupils in relation to the educational level of their father 


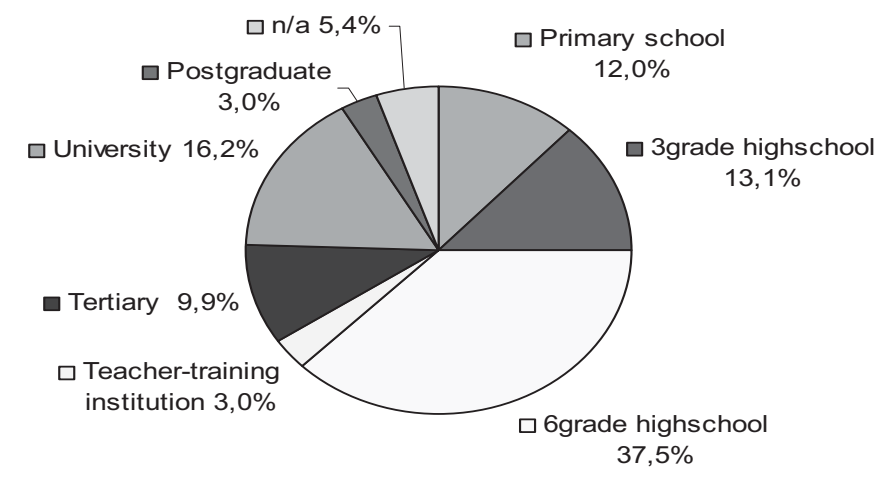

Figure 4. Percentages of the pupils in relation to the educational level of their mother

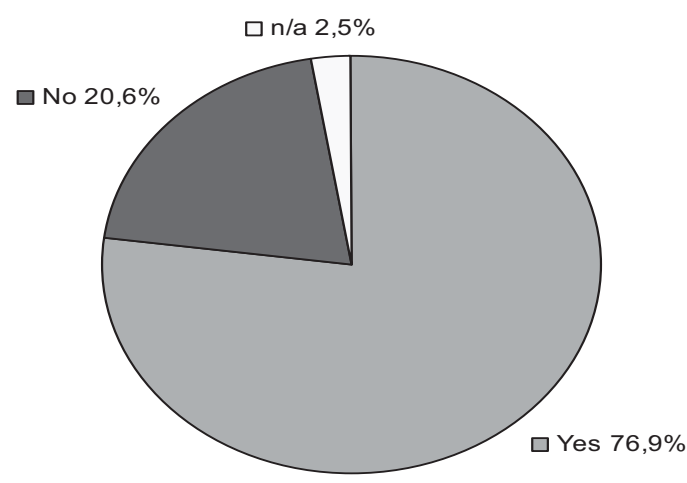

Figure 5. Percentages of pupils in relation to their answers to the question whether they are fond of folktales

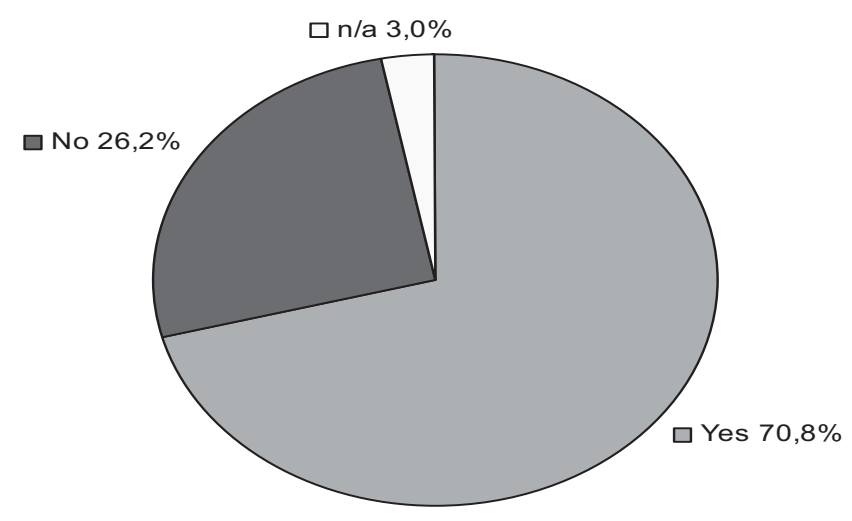

Figure 6. Percentages of boys in relation to their answers to the question whether they are fond of folktales 


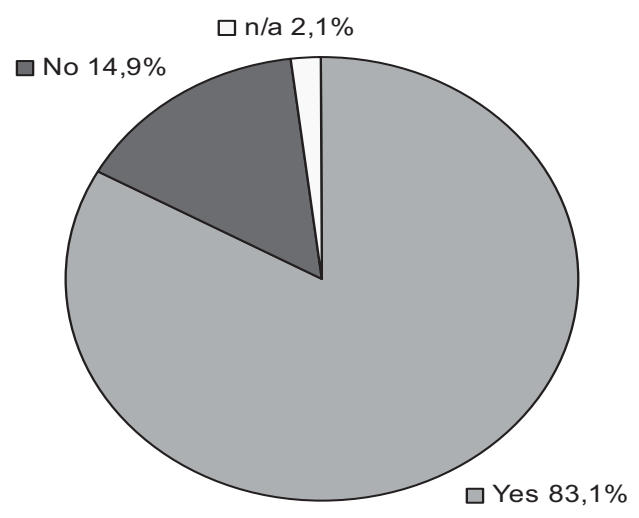

Figure 7. Percentages of girls in relation to their answers to the question whether they are fond of folktales

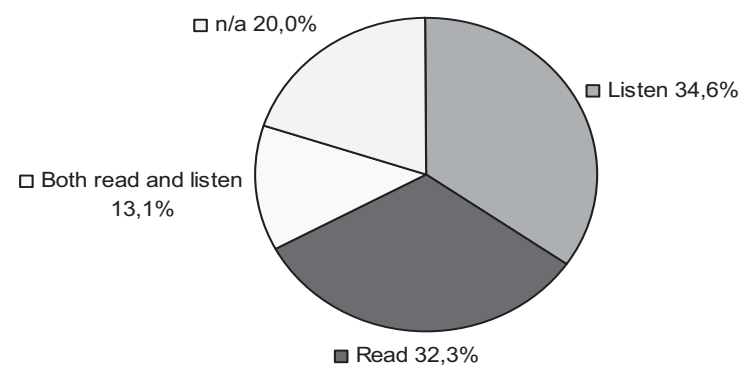

Figure 8. Percentages of pupils in relations to their preferences about hearing or reading folktales

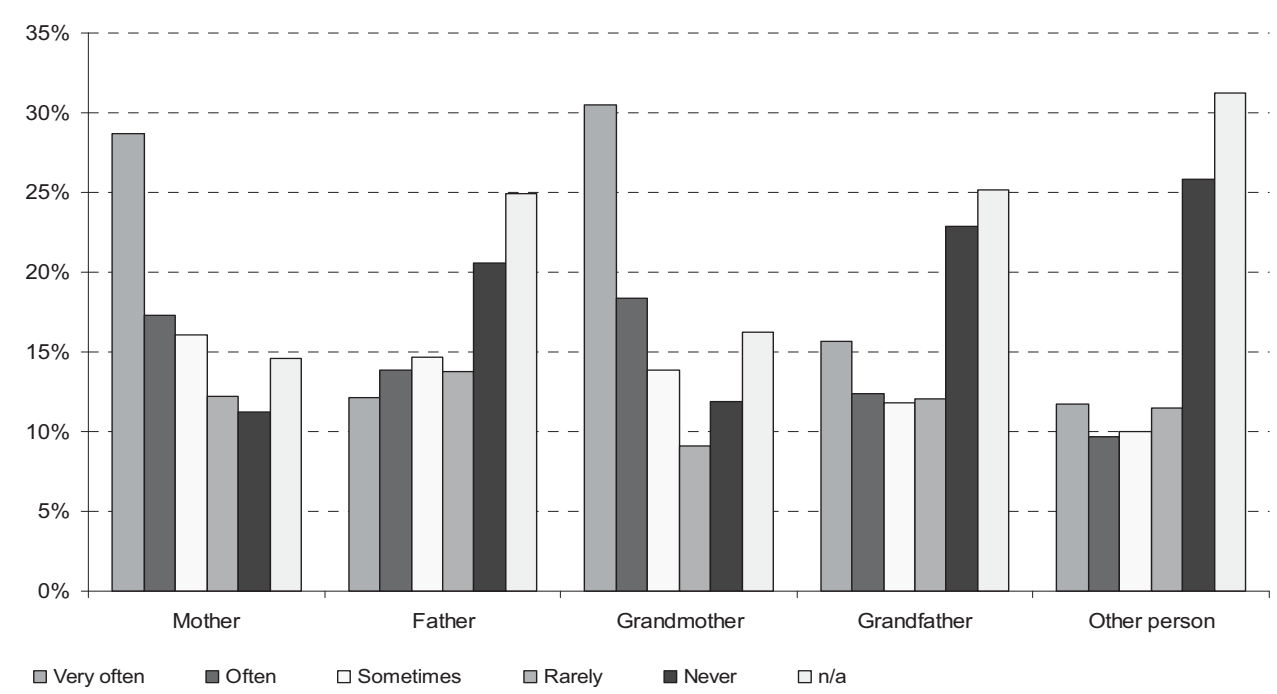

Figure 9. Percentages of the pupils in relation to the persons in the family who tell them folktales 


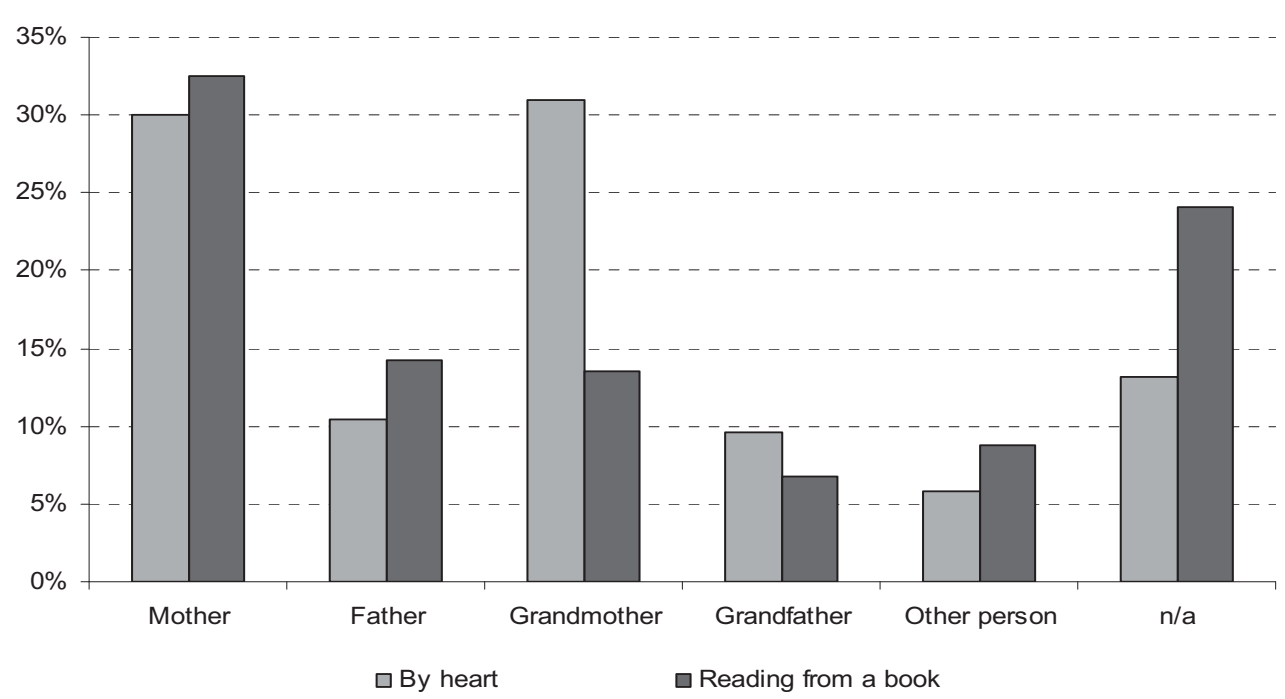

Figure 10. Percentages of the pupils in relation with the kind of narration and the family members who narrate to them

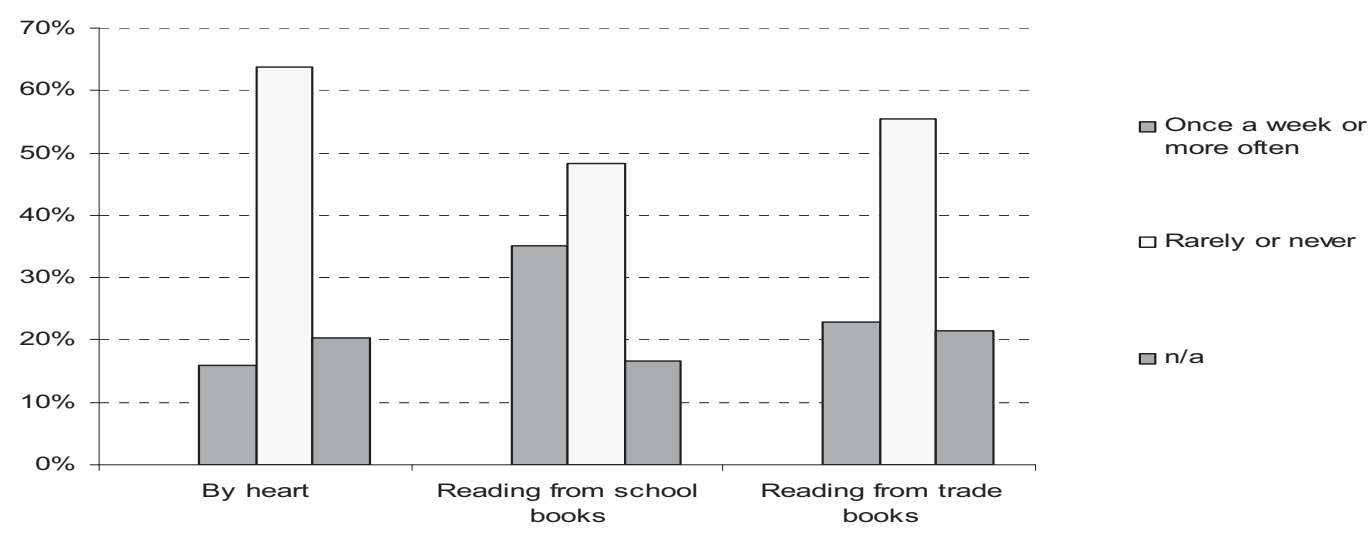

Figure 11. Percentages of the pupils in relation to folktales they hear in school

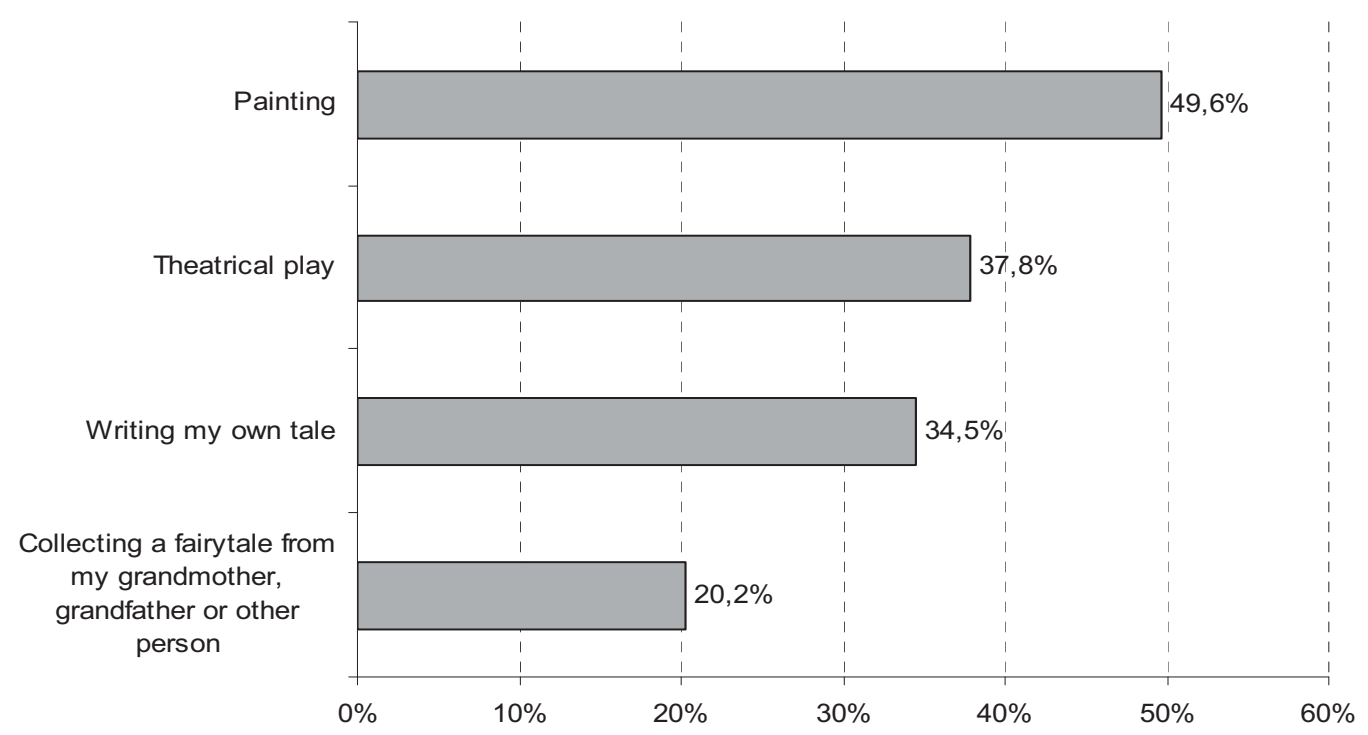

Figure 12. Other activities related with storytelling in school 


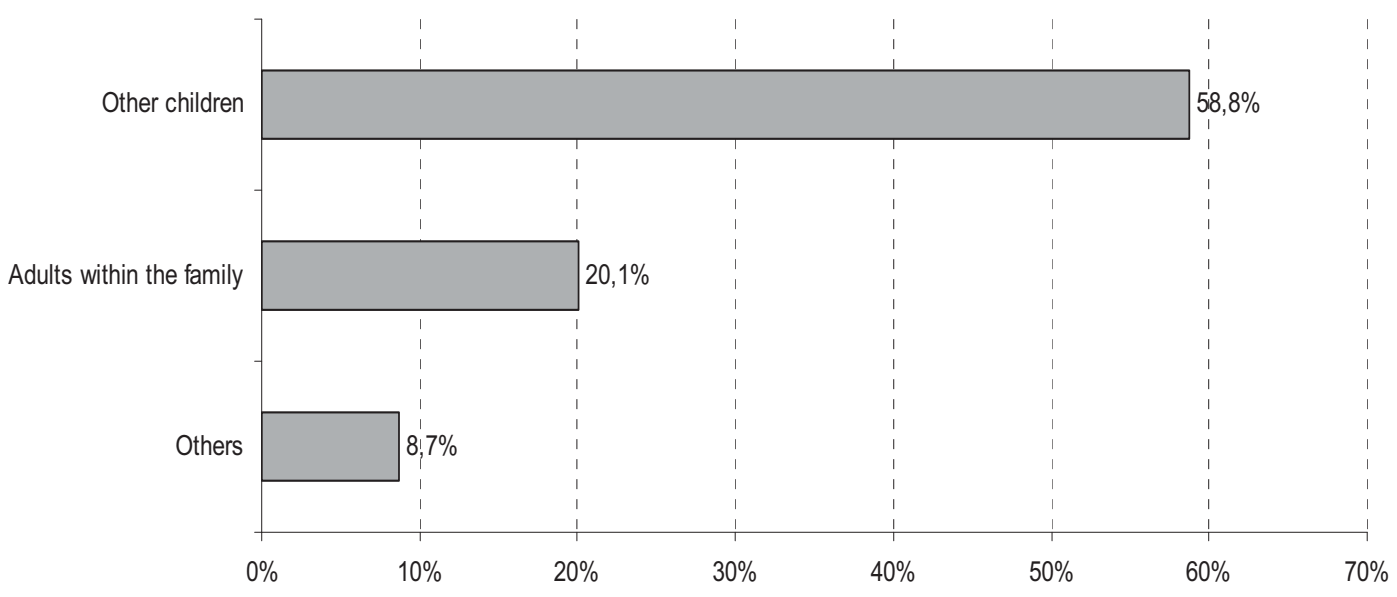

Figure 13. To whom the pupils themselves narrate folktales?

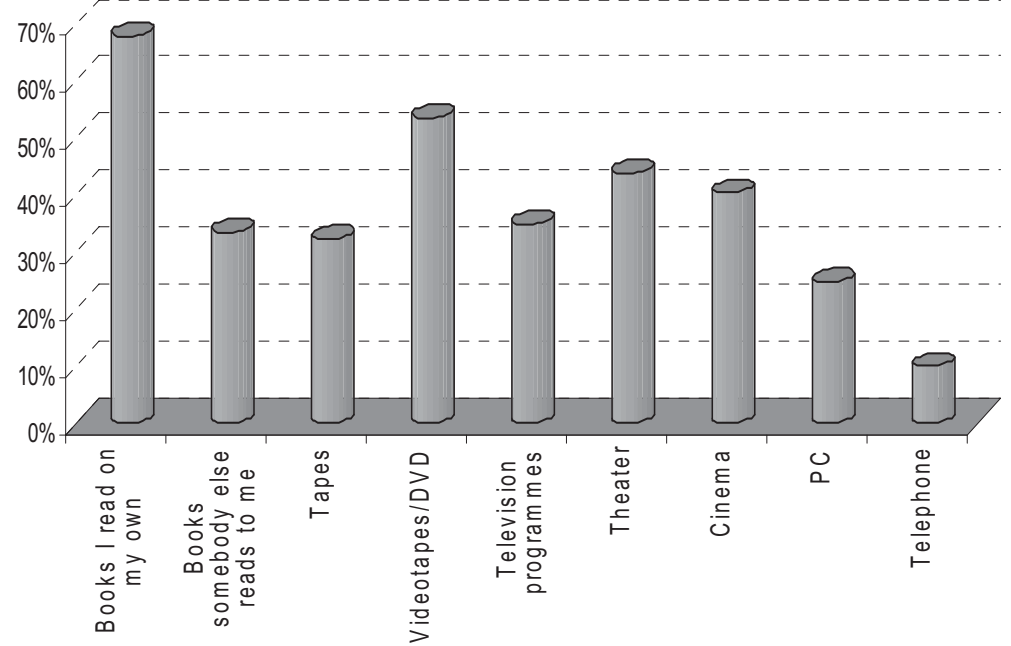

Figure 14. Sources of folk and fairytales apart oral storytelling 


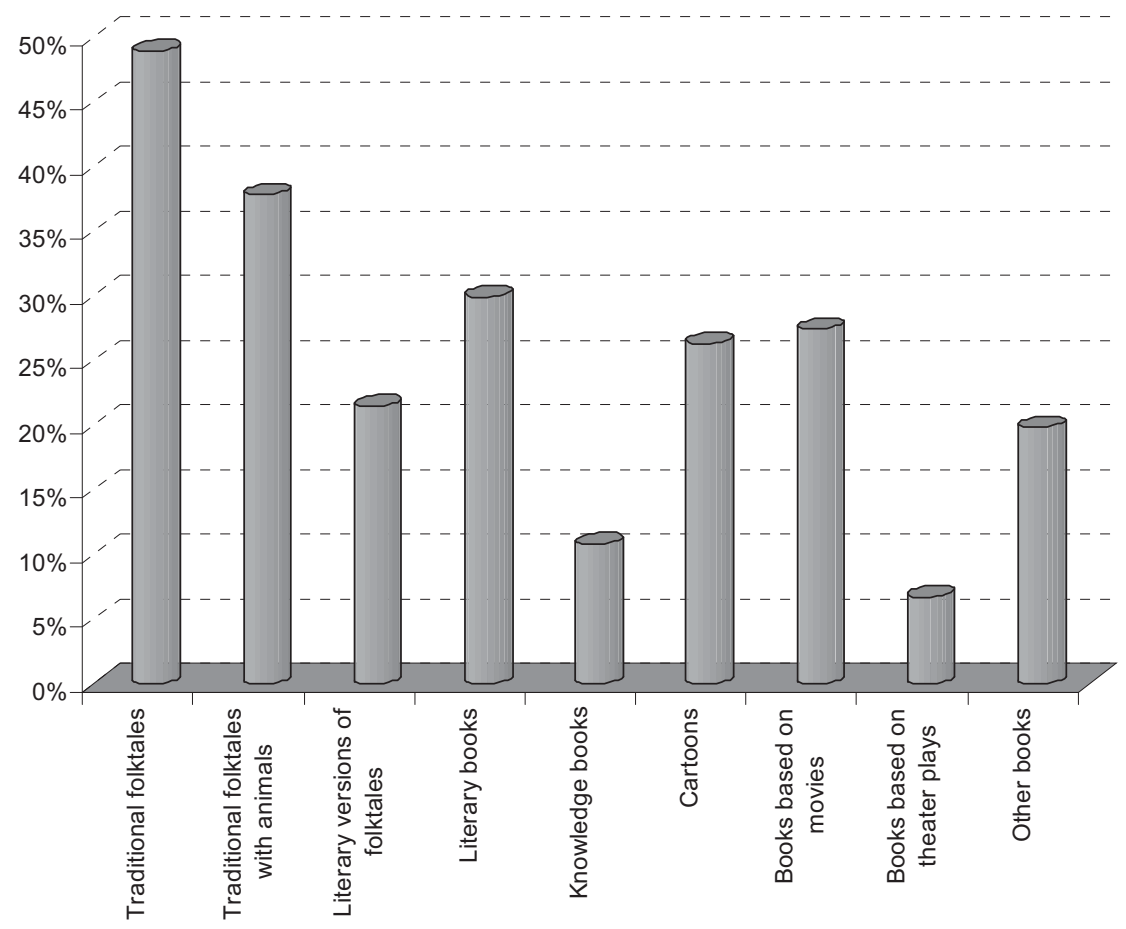

Figure 15. Percentages of the pupils in relation to the kind of folktales the know

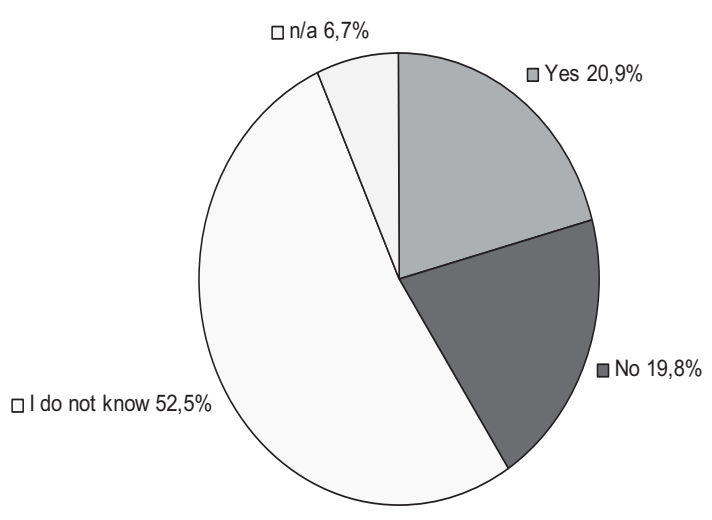

Figure 16. Opinions of the pupils in relation to the international character of the folktale 